811.163.41'354"18"'

821.163.41.08 Петровић Његош П. II $811.163 .41 ' 282^{\prime} 34^{66} 18^{66}$

https://doi.org/10.18485/sj.2018.23.1.18

МИОДРАГ В. ЈОВАНОВИТ ${ }^{*}$

Универзитет Црне Горе

Филолошки факултет у Никшићу
Оригинални научни рад

Примљен: 04. 01. 2018.

Прихваћен: 29. 01. 2018.

\title{
НЕКЕ ФОНЕТСКО-ФОНОЛОШКЕ ЦРТЕ ПИСМЕНИЦЕ У ПОРЕЪЕЊУ СА ГОРСКИМ ВИЈЕНЦЕМ И ГОВОРИМА ВУКОВА И ЊЕГОШЕВА КРАЈА
}

Анализирају се одређене фонетско-фонолошке карактеристике Вукове Писменице и Његошева Горског вијенца - судбина неких сугласничких група (асимилације, дисимилације, упроштавања), појединих сугласника подложних промјенама, у првом реду. Колико језик Горског вијенца иде у правцу заснивања Вуковог модела књижевног језика, замишљеног у препорукама из Писменице, или је снага и моћ Његошеве мисли остварена избором и ткањем у стихове првенствено дијалекатских завичајних ликова, што су поједини лингвисти, у анализама језика Горског вијенца, пренаглашавали. То су била само нека од питања у овом раду.

Кључне речи: Писменица, Горски вијенац, тршићки говор, његушки говор, сугласничке групе, сугласник $\phi$, алтернације сугласника, књижевни језик

1. Овим радом пратимо одређене фонетско-фонолошке особине Вукова и Његошева језика, а намјеравамо да остваримо неколика циља: да представимо у којем се степену у језику Горског вијенца огледа дијалекатски карактер, што су поједини лингвисти пренаглашено овом пјеснику спочитавали ${ }^{1}$, односно,

\footnotetext{
*jmisko@ac.me

${ }^{1}$ „То је само сирова уско цетињско-његушка дијалекатска грађа” [Младеновић 1989: 224]; „Јасно се види да је Његошев језик углавном народни језик и то онакав какав се говори у Црној Гори" [Вушовић 2013: 186]; чак је такво и мишљење Матије Бећковића који Његоша сматра
} 
гледајући из друге перспективе, колико је Његошев избор језичких средстава у складу са Вуковим моделом књижевног језика, какав је овај реформатор дао у Писменици из 1814. године ${ }^{2}$, у којој је, како је и сам нагласио, само дао „нека правила о скланьаньу имена и мїестоимениїа, и о спрезаньу глагола...” (Писменица сербскога їезика, Предсловлье, IX), односно колико су она могла бити уграђена у метрику пјесниковог стиха. Такође, било је важно видјети да ли су Вукова језичка правила, озакоњена у Писменици, идентична са народним говорима било ког краја наше језичке области па и са стањем у његовом завичају или говорима његових предака - он је рођен у породици која је напустила стари завичај скоро осам деценија прије настанка његове прве граматике. На тај начин ће се потпуније сагледати колико су неке црте блиске или удаљене од данашње фонетике (и морфологије) књижевног језика и говора чији су изворни представници ова два писца, а недвосмислено је да су језичке особине на које се овдје осврћемо првенствено значајне за историјску дијалектологију. Вук је први утврдио системе народног језика, углавном гласовне и морфолошке, ако не и сасвим прецизне на самом почетку, тј. када је писао своје граматике - Писменицу и Граматику уз прво издање свог Рјечника, с корекцијама које је он сам у току свога живота и рада учинио [Стевановић 1963-1964: 74]. Логична је претпоставка да с обзиром на природу дјела Вука Караџића и Петра II Петровића Његоша - Писменица научно, а Горски вијенац пјесничко - да ни језик не може бити једнак у обојице. То смо и досад доказивали у нашим радовима, интересујући се за рефлексе јата, судбину сугласника $x$, вокалске групе, дистрибуцију покретних вокала, самогласничко $p$, придјевско-замјеничке ријечи и друге карактеристике Вуковог и Његошевог дјела. Овај рад, дакле, наставак је наших раније започетих истраживања.

\section{COHAHT $J$}

2.1. Сонант $j$ у императиву. Реализација финалног и медијалног $j$ за „наклоненье заповїедателно" (императив) код Вука и Његоша се разликује. Императив глагола $\mathrm{V}$ врсте, како се сугерише у Писменици, формира се према узусима књижевног језика: „Наклоненье заповїедателно. Друго лице се саставльа од первог оконченьа с измїеном $м$ на $\ddot{l}$, н. п. чувам, чуваї ти, играм играї; ... второ лице множ. броїа производи се од второга лица овога наклоненьа, с додатком те, н. п. чуваїте ви” (72). „Наклоненье заповїедателно”: подаїте (50); биваї

највећим пјесником српског језика од Светог Саве до данас: „На говору катунске нахије настао је спев каквих је најмање и на највећим светским језицима" [Бећковић 2013: 304].

${ }^{2}$ Упућивања на Писменицу односе се на издање: Писменица сербскога їезика, по говору простога народа написана Вуком Стефановићем Сербиїанцем, у Виенни, 1814, У печатньи Г. Иоанна Шнирера, 1-107. Упућивања на Вијенац односе се на издање: Петар II Петровић Његош, Горски вијенац, Цетиње - Београд, Обод - Просвета, 1975. 
ти (58); да бивамо ми, биваїте ви (58); „Наклоненье заповїедателно: Време садашнье, и будуште”: да карамо ми, караї ти, караїте ви (65); „Наклоненье заповїедателно. Време садашнье, и будуште": караїсе ти, караїтесе ви (98) - уз стабилну употребу сонанта $j$ и у медијалној и у финалној позицији (сонант $j$ означава се у Писменици знаком i). Александар Младеновић у раду Језичке особине Вукова краја из 1861. године (320) наводи облике са испуштањем изговора овога гласа и у финалној: исприча(j); и у медијалној позицији: дотера(j)me. Иначе је, по мишљењу овога истраживача, изговор овога гласа посебно нестабилан у позицијама сантхија: покра(j) њега, својо(j) кући, он jo(j) рекну, он jo(j) даде [Младеновић 1963-1964: 320]. У народним говорима Његошевог краја облици императива 2. л. једнине (финална позиција) и 2. л. множине (медијална позиција) најчешће су са пропуштањем изговора овога гласа (иако се употребљавају и књижевни ликови). Обје варијанте уткане су у метрику стиха Горског вијенца, с тим што су књижевне форме у финалној позицији обичније: Oтавара' јој књиге на пророке (836); за горске се госте не приправља' (1159); те прочита' да знамо што пише (2061); исприча' ни штогод аманати (2242); // Слушај, Вуче, и остала браћо (520); пошто мркни и пошто вечерај (1533); Кад погледај онога кокота (1589); и притискај земље и градове (1455); а у медијалној позицији су обавезне: „Погледајте онога кокота” (1588); ал' чувајте да вас јад не нађе (1595); Сад ми дајте једну чашу вина (2443); Причајте ми што је тамо било (2583).

Пропуштање писања сонанта $j$ - и у финалној: $\partial a(j)$, исприча $(j)$, и у медијалној претконсонантској позицији ( $\partial a(j) m e)$ код Његоша биљежи и Данило Вушовић, с тим што се његово губљење констатује и у другим пјесниковим дјелима у међувокалској позицији: издаице, Бамще, твоега, чуем и др. [Вушовић 2013: 186], што се у стиховима Горског вијенца није могло потврдити.

Код глагола IV врсте у говорима Тршића и околине у 2. л. једнине императива напиј се [Николић Б. 1968: 421]. Ипак, на другом мјесту у својој монографији (стр. 406) овај истраживач упућује и на његову другачију судбину код овог глагола у финалној позицији: $n \hat{u} j=n \hat{\text {. }}$ У Горском вијенцу, у једином примјеру који смо пронашли, финално $j$ је реализовано: Пиј шербета из чаше свечеве (767); исто тако и у императивној рјечци немој/немојте, која у његушком говору најчешће гласи немо/немоте: Немој који грозда окинути! (1596); а једнако, немој се варати (548); Не, Рогане, немој га будити (1255); Дану, Вуче, немој прекидати (1753); Ништа ми се немојте чудити (521). У рјечци немој їсе налази и у језику Писменице: ова їе риеч дела верло обична код нашега народа, и свакад значи на против немої (61). Са сонантом $\ddot{\imath}$ на крају су „у втором лицу їед. броїа, глаголи, коїи се окончаваїу на $\ddot{i}$ и $\mathcal{M}$, они саставльаїу ово наклоненье с изоставльеньем им, н. п. броїм, брої; кроїм, крої, и пр.”; а у том лику (број) регистрован је и у тршићком говору" [Николић Б. 1968: 421]. 
2.2. Финално $j$ у показној замјеници за друго лице тај у Горском вијенцу и Писменици има различиту судбину, док је Његош употребљава само у дијалекатском лику: Гроб се његов пропа на та свијет (2425); Нек уљезе и $m a$ луди к нама (2735); код Вука је постојано - говорећи о „Мїестоимениїу (указателна)” он прописује искључиво лик са $̈:$ : maї (44); „мужески оваї, maї, онаї; женски ова, та, она" (41). Међутим, Александар Младеновић у говорима Вукова краја помиње дублет - са изговореним и неизговореним гласом $j$ : ma(j)/maj [Младеновић 1963-1964: 297].

2.3. Финална секвенца -ији (компаратив, придјеви, замјенице). Ова секвенца, најчешће потврђена у компаративу/суперлативу ${ }^{3}$, код ова два ствараоца иде различитим путевима - Његошев језик привржен је дијалекатској бази гдје придјеви који граде компаратив наставком -uj, у мушком роду, послије губљења сонанта $j$, имају, готово без изузетка сажету форму: а воли бих да надјача мањи (1205); ал' је згодни али је ваљасти (1983); ал' је мудри али је љубавни! (1984); а у Писменици постоје само књижевне: Оваї човек учениїи него онаї (34); окорелиїи (34); наїпростиїи Сербльин разуме све (6); храбри, храбриїи (34). Процес -ији > -и потврђен је у Горском вијенцу и код именица: Благо Андри ђе је погинуо (1305).

2.4. Финална вокалска група -ио. Готово редовно биљежење сонанта $j$ у радовима дијалектолога - јер је изговор овога гласа између вокала $u$ и $o$ позиционо условљен - није преточено у писану ријеч ни Писменице ни Горског вијенца: у оба извора неизмијењена финална група -ио једина је варијанта. Горски вијенац: који га је млеком одранио (637); да је бјеше Србин уграбио (488); дим те црни бјеше приклопио (1743); те срамотно црн му образ био! (2005). Писменица: ти би био (55); їа би творио (89); у коїему сам се їа потрудио (IX). Но, за разлику од Његоша, Вук није досљедан у неким другим радовима, гдје сугерише да се пише: „донијо, иијо, бијо (...) зато што се послије каже донијела, донијело, иијела, иијело...” [Пецо 1963-1964: 213].

2.5. Финална вокалска група -ajy. Нема у Његошевом језику (ни Горског вијенца ни других његових дјела) дијалекатског лика 3. л. множине презента глагола $-a /-a$ основа $-a(j) y$, који је у старијим црногорским говорима, па и говорима пјесниковог ужег завичаја (цетињско-подловћенског типа), код глагола V врсте, доста обичан (мотау, копау, играу). Редовност фонетског лика -ajy може се потврдити великим бројем примјера: ђе на коноп скачу и играју (1577); сада пушке највише пуиају (2568); па на рају страву ударају (2744). Јасно је што је ова секвенца и у Писменици стабилна: и другим глаголима

\footnotetext{
${ }^{3}$ Финалном секвенцом -ији у Вуковом, Његошевом језику и народним говорима детаљније смо се бавили у радовима: Финалне вокалске групе и покретни вокали у Вуковој Писменици и Његочевом Горском вијениу [Јовановић 2014: 12-13]; и Придјевско-замјеничке ријечи у Горском вијениу [Јовановић 2013: 61].
} 
пришиваїу (60); нити ће рећи да нам требаӥу (5); коїа неимаїу їедин. броїа (25); скланьаӥу се у обадва броїа (40); Они, е, а биваїу (56); ако они, е, а узбиваїу (59); Нека они, е, а, чуваїу (72) - јер је такве природе и у говору Тршића: играју ce, имају, дају [Николић Б. 1968: 420]. С обзиром на то да су у језику Горског вијенца процеси $x>\varnothing$, у завршном интервокалном положају, тј. у 3. лицу множине имперфекта, остали непознати: те немаху крви у образу (1428); Они wћaxy све онако појат (1904); кажи оно што они збораху (1511); Од тога ти бјеху погинули (1515); избјегнута је могућност формалног изједначења 3. л. множине презента и имперфекта (играу, варау, ударау), иначе јако израженој појави у старијим црногорским говорима [Стевановић 1935: 29-30]. Нема те једнакости ни код Вука: иако сугласника $x$ нема у језику Писменице, сонант $j$ (i) је, како смо видјели, стабилан - овакво стање потврдиће и само један примјер, у којем налазимо употријебљен и презент и имперфекат: Льуди сnаваїу; дерва гора(x)y (46).

\section{3. СУГЛАСНИК $Ф$}

3.1. Два извора, Горски вијенац и Писменица, ни судбином сугласника $\phi$ нијесу потпуно сагласни. Иако Вук међу 24 писмена „коїа у нас има и коїа се не могу изговорити без помоћи устана, їзика, зуба и остали орудиїа говореньа" убраја и сугласник $\phi$ (стр. 9-10), ипак оставља одређену резерву: „Писме $\phi$, само їе за тудье риечи, а Сербске ни їедне риечи неїма гди би оно требало; и зато га прости Сербльи у говору, свуд готово, промїеньуїу на в" (стр. 10). Кад је овако писао овај реформатор је свакако имао увид и у ситуацију у свом тршићком говору: „И данас, сугласник $\phi$ Тршићани радо замењују сугласником в: ва̀милија, ваิрба, ваิрбом, вёс, вишѐклија, трёвимо. Може се, међутим, чути и p: фёс, фа̀милија [Николић Б. 1968: 159]. И у говору Вукових предака умјесто $\phi$ најчешће се употребљава $в$ [Вуковић 1938-1939: 27]. У Горском вијенцу је, баш као и у његушком говору, стабилна употреба овога гласа - нема мијешања са в ни у области старије лексике ни у новијим позајмљеницама: само факир остави фукару (1819); Франиускога да не би бријега (7); Више жалим пуста цефердара $(2797)^{4}$; ни прекова бистра цефердара (2815); какав фишек на поклон везиру (1179); фриштијаху хиљаде момаках (1746); Не сердаре; али што зафајду? (2007); ђе Софија за коњушку служи (2279). Но, и у погледу употребе сугласника $\phi$ језик Горског вијенца, у односу на пишчев завичајни његушки говор, показује одређене посебности: лексема лав увијек је у овом спјеву са реализованим финалним $\phi$ (како губљење звучности сугласника на

\footnotetext{
${ }^{4}$ У језику Петра Првог Петровића Његоша, па и савременика творца Горског вијенца, знаменитог писца из Паштровића, Стефана Митрова Љубише, код ове лексеме имамо дублет цефердар/цевердар [Остојић, 1976: 103].
} 
крају ријечи није особина његушког говора, тако ни редовни прелаз $в>\phi$ у овој лексеми није очекиван): бораше се као лаф с Турцима (568); но што стрепи лаф од гуске, кажи? (805); штавише, прелаз в > $\phi$ се, по узору на финалну, усталио и у медијалној позицији: Из грмена великога лафу изаћ трудно није (Посвета, 9); постадоше лафи ратарима (259); малом мраву ка гордоме лафу (756); Лажу људи што за лафа кажу (1097)5.

3.2. У говорима Вуковог и Његошевог краја сугласник $\phi$ може бити и у резултату упрошћавања сугласничке групе $x \boldsymbol{~ - ~ ( и ~ у ~ и н и ц и ј а л н о ј ~ и ~ у ~ м е д и ј а л н о ј ~}$ позицији). Али ни ту, посебно код Вука, ситуација није једнодимензионална и сасвим проста. Наиме, Вуков језик у његовим раним радовима подудара се са тршићким говором у којем постоји дублет ва́ла/ хват- основа: у̀ват (и)ла, у̀ват(и)ли [Николић Б. 1958: 270]. Ипак, петнаестак година касније овај дијалектолог унеколико коригује изречено мишљење и каже како код Вука из овог периода (1817. година) има лик вали [Николић Б. 1963-1964: 159]. У говорима завичаја Вукових предака и сродним говорима који су ушли у основицу српског књижевног језика група $x \varepsilon^{-}$, без разлике и код хват- и код хвал- основа, дала је, пропуштањем изговора сугласника $x$, редовно в: ваิлйн те бӧже, ва́лити, прѝватйм [Вуковић, 1938-1939: 34; Станић, 1974: 95]. С друге стране, Његош се у Горском вијенцу дистанцира од стања у његушком говору, гдје је ова сугласничка група прешла у $\phi$, јер је у овом његовом дјелу стабилна - и код хват-: а не бисте ниједну хватали (195); Докле свако за по грозд ухвати (1597); домамили па их похватали (1449); и кулу му бјеше дохватио! (2772); и код хвал- основа: Што се хвалиш градом и господством (385); Ефендија, овако ти хвала! (934); Хвала богу има ли вјештицах? (2173). Усамљен је један примјер (хвал- основе) у којем је почетно хв-, као и у завичајном говору писца, прешло у $\phi$ : Фала богу, јест велико чудо! (1674).

\section{4. АЛТЕРНАЦИЈЕ СУГЛАСНИКА}

4.1. Алтернација з/ж. Дистрибуција сугласника з и ж, обично у различитим формама глагола (-)казивати, код Његоша и Вука различито је спроведена. У Горском вијенцу, у складу са приликама у народном говору, успостављен је однос непалатални сугласник у књижевном језику (-)казиват/палатални сугласник у спјеву (-)каживат: траг да му се по прсту кажује (1053); кажуј, бабо, рашта си лагала (2184); да пас пасу довијек кажује (355); и кажује бог је посјекао (2131). И у језику Писменице (али различито од Горског вијенца) стање је идентично са Вуковим народним говором, и слаже се са књижевном нормом - углавном су то примјери 3 . л. јд. и мн. презента глагола показивати:

${ }^{5}$ Сонант в, губећи звучност, понекад прелази у ф у овој лексеми у црмничком говору [Милетић, 1940: 360]; а потврђена је у лику лаф и у језику С. М. Љубише [Тепавчевић, 2010: 110]. 
Име суштествително зове се оно, коїе показуїе какво лице (16); с коїим се показуїе чиїе їе што (19); Време будуште, коїе показуе [са изостављеним $і ̈ \mathrm{y}$ овој позицији, што се такође може потврдити у говору Тршића] да дїеланье или страданье їошт ниїе настало (50); коїи различне страсти показуїе (103); имена броїтелна показуїу четири рода (36); Мїестоимениїа показуїу четири рода (41); коїа показуїу време (102); рјеђе и у неким глаголима са другим префиксима: у извїестном времену сказуїе (48); коїему се што о ствари какової опредіелено и їавно сказуїе (50); у коїему се сказуїе нешто о ствари (50); Указателна мїестоимениїа зову се она, коїа што указуїу или опредїельуїу (44). Исто стање у говору Тршића потврђују и дијалектолози: „Глаголи типа казивати мењају се као у књ. језику: 1. л. мн. през. ка̀зујемо; глаг. прид. радни м. р. јд. кази́во̆” [Николић Б. 1968: 429].

4.2. Рефлекси палатализације и сибиларизације. Веома је мало, и код једног и код другог, одступања од правилног вршења ова два гласовна процеса. Вук у Писменици (24) прописује правило сибиларизације које и сам поштује: „Имена, коїа се окончаваїу на га, $x a$, у дат. їед. промїеньуїу г на з, $\kappa$ на $u$, а $x$ на $c$, н. п. кньига, їабука, снаха; дателни кньизи, їабуци, снаси (24); (...) од рука, їабука, нога и пр. Сербльин никад неће казати у дат. їед. руки, їабуки, ноги; него: носи у руци; виси на ̈̈абуци; има рану на нози и пр.” (24); „Ви сте и к ової струци общтеполезнога добра" (VII). Међутим, код њега се касније, посебно у препискама, може наћи и по који примјер са неизмијењеним задњонепчаним сугласником к: препоруки (Преписка I, 177), библиотеки (Преписка II, 231) [Пецо, 1963-1964: 214]. Ријетка одступања од књижевне норме у језику Горског вијенца иду у правцу проширења резултата сибиларизације - у атрибутској ријечи једнаки, у једном је стиху: Седам брата, сви седам једнаци (2013), те придјевској замјеници свиколици, у једном невезаном слогу, иза стиха 2217: Разиђоше се дома свиколици, што је иначе заједничка особина свим говорима староцрногорским (нарочито је живе употребе на Приморју). Од лексеме снаха пјесник употребљава датив једнине снахи: па се снахи не дао острићи (1298), а остаје као неискоришћена могућност књижевни дублет снаси, те дијалекатски ликови ширег ареала: снаји или снаи. Обавезност изговора сугласника $u$ (и ч у презенту) Вук у Писменици (84) уочава и у императиву глагола „кої се окончаваїу на чем, промїеньуїу ч на $u$, н. п. печем пеции, вучем вуци, тучем туци, сїечем сіеци; но ови се глаголи изузимаїу само у втором лицу їед. и мн. броїа, а остала лица саставльаїу, као и остали глаголи"; у презенту и имперфекту: печем-пецијах, тучем-туцијах, сїчем-сїцијах, вучем-вуцијах (82). Обавезне промјене задњонепчаних сугласника, и сибиланта з, у предњонепчане или зубне сугласнике (у вок. јд. и множ. падежима) Вук у Писменици још на једном мјесту прописује: „Имена, коїа се окончаваїу на $2,3, \kappa, x$, у зват. їедин. премїеньуїу г и з на $ж, \kappa$ на $\psi$, а $x$ на $w$; а у множ. именит. и у дат. 2 на з, $\kappa$ на $u$, а $x$ на $c$, н. п. рог, кнез, путник, Влах, у зват. їед. роже, кнеже; путниче, Влаше; 
а у множ. имен. рози или рогови, путници, Власи, у дат. и у твор. розима или роговима; путницимма, Власима" (21-22); двоїи рози (39).

4.3. Коријен остр-/оштр-. За разлику од говора Његошевог ужег завичаја, па и много шире арее, код лексеме оштар језик Горског вијенца (и у другим његовим дјелима) сачувао је из старине неизмијењени коријен остр-, како у придјевима: већ умију под грлом острити (119); Твоје куле и остре мунаре (926); ко ће турске главе сјећи/остра сабљо? (1931); остро осје одбрањује класје (2304); тако и у другим ријечима изведеним од овог коријена: до што остре зубе за сусједе (1161); зубовах је туште изострила (2306); друга сину од Скадра к Острогу (174). У дијалекту Његошеве средине, а то су катунски говори, потврђени су двојаки ликови - са остр- и оштр- у коријену: оштрити, оштримице//oстар, острити, остримице - са претежнијим ликовима књижевног језика. Неизмијењени сугласник $c$ у коријену остр-, односно удаљавање пјесниковог језика од стања у дијалекту (у Његошевом Речнику ${ }^{6}$ и нема придјева оштар и од њега изведених ријечи у лику са $w$ ) Стевановић објашњава таквим ликом у руском језику, односно црквеноруском, који зна једино за коријен остр-) - „у питању је утицај језика најомиљеније Његошеве лектире, него зато што је био понесен архаичношћу тога лика као народног”7 .

Коријен остр- потврђен је и код Вука у Писменици (106): Херцеговци све риечи изговараїу берже и остриїе; док за тршићки говор његов испитивач констатује само књижевну реализацију сугласничке групе -стр- у придјеву оштар [Николић Б. 1968: 409].

4.4. Алтернације $\mathrm{cm} / \mathrm{mm} / \mathrm{u \hbar}$. Код глагола од основа (-)nycmu у дистрибуцији $\mathrm{cm} /$ шт Његош бира народне фонетске ликове (са шт): и пуштит га задовијек неће (962); Мрцино нам круну не упушти (1824); Не пушт', Бајо, жива ђавољега (1852); спушти куље, а обриши брке (1683); не пуштише жива ниједнога (598); Пуштите их, аманат ви божи (193); не пушта се да је зло поб’једи (2313); и пуштит га задовијек неће (962). У тршићком говору итеративни глагол пуштати показује већу шароликост - напоредо са пуштати употребљавају се и варијанте пушћати и пустати, презент: допушћа, пушћа, nустају [Николић Б. 1968: 407; Младеновић 1963-1964: 318]. Имперфекат је

\footnotetext{
${ }^{6}$ Речник језика Петра II Петровића Његоша израдили су: Михаило Стевановић и сарадници Милица Вујанић, Милан Одавић и Милосав Тешић. Издавач САНУ и др., Београд 1983.

${ }^{7}$ Ако неко и не прихвата да је коријен остр- русизам (већ досљедно чување старог стања у Његошевом језику), ипак не може сматрати ријечи острота и острост домаћим, а које су употријебљене и у Горском вијенцу: пред остротом витога челика? (884); и у Лучи микрокозма: сваку острост зуба у тартару (309), него несумњиво као руске, односно црквеноруске. „Њих нема у другим нашим речницима сх. језика осим Речника Матице српске, у коме су донете заједно пошто имају исто значење, потврђено управо са ова два примера из Његоша. А то је доказ да се ни после њега нису одомаћиле иако нису у супротности с принципом творбе у нашем језику" [Стевановић 1990: 239].
} 
у Горском вијенцу у складу са књижевном нормом (са секвенцом $и т$ ), али особене творбе: Cпуштавах се ја на ваше уже (1169); Не био их пуштават од себе (2530). Између форми $ш т$ и $ш \hbar$ у трпном глаголском придјеву од глагола (-)крстити у Горском вијенцу се налази само $u \hbar$ : светим пићем богом закрићеним (586); Шишано је исто ка крићено (1042); прекрићени на огњу бадњаци (2461); Што ће ђаво у крићену земљу? (306); редовно је и у Тршићу кршћен, раскршћено - чак и код неких итератива VI Белићеве врсте

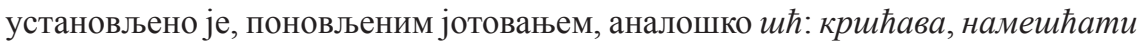
[Николић Б. 1968: 407]. И у Горском вијенцу и у Писменици употријебљен је презент (у Горском вијенцу и аорист) глагола искати: Иите свијет неко дјеиствије (2298); чаша жучи иште чашу меда (565); душа ми их ваистину uште (2448); обећа ми и што му не исках! (1655); док тршићки говор и код овог глагола нуди различите ликове: през. глагола искати гласи йска = йште

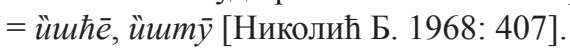

\section{5. УПРОШТАВАњЕ СУГЛАСНИЧКИ ГРУПА}

5.1. Сугласничке групе жј, чј. Из даље прошлости су језичке појаве везане за колебљивост у дистрибуцији сугласничких група жј, чј. Староцрногорски говори, којима припада и Његошев, наслиједили су старо стање, када се сонант j у додиру са овим предњонепчаним сугласницима (некада палаталним) губило (божи, овчи). У Горском вијенцу је појава губљења сонанта $j$ посвједочена у само два стиха: Пуштите их, аманат ви божи (193); ко ли божа прозрети чудеca? (2221), а разлоге нам М. Стевановић, с правом, овако предочава: „Овде се ништа друго не може претпоставити већ да је песник изговор средине осећао као свој, али је познавао и изговор и писање ове речи и код Вука и других књижевника свога времена, па то на два начина у исти мах написао, а да ту и не осети никакве разлике" [Стевановић 1990: 218]. Изузев ова два примјера, редован је фонетизам јu, ja, је...: Бич сам божји ја сплетен за тебе (390); Бог са нама и анђели божји (663); Ема нећу, божја ви је вјера (941); ма залуду, на ти божју вјеру! (684); предјел шири видиш божје силе (908). За књижевни дублет овог придјева, за двосложни рефлекс -ији (божији), у Горском вијенцу, ни другим Његошевим дјелима, немамо потврде ${ }^{8}$.

\footnotetext{
${ }^{8}$ Пишући о Његошу, у раду Житије Светог митрополита Петра Другог - иетињског пустињака и ловћенског тајновидца, митрополит Амфилохије (Радовић) напоредо употребљава Божији и Божи - при чему, ликови са двосложним рефлексом имају изразиту превагу: у страху Божијем (289); као воље Божије (291); За њега Бог и Божија сила (292); свеукупне Божије творевине (293); на славу Божију (295); на тврдој Божијој вјери, на страху Божијем (296); свеукупна Творевина Божија (297); није ли и то неко Божије знамење? (299); као кад служи службу Божију (300); и то је знамење Божије (301); овог изабраника Божијег (301); Божији одабраниче
} 
Са секвенцом жј увијек је у Горском вијенцу придјев вражји, ја...: вражје племе позоба народе (20); Не бојим се од вражјега кота (528); Вражја сила одсвуд оклопила (646); А каква је то вражја женидба (1766). Међутим, у неким другим пјесниковим дјелима појављује се и лик вражи, а такви су примјери дати у Речнику Његошева језика [Стевановић 1990: 218]. Именице са сугласничком групом жј у свом саставу: оружје (за ову лексему постоји највећи број примјера), обиљежје... имају стабилан неупроштени лик - и у Горском вијенцу и у другим Његошевим дјелима, и у говорима његовог завичаја: Почину ни рђа на оружје (282); крваве му руке и оружје (590); Ко гођ паше свијетло оружје (669); и оружјем, мојијем уздањем (865); на свакога токе и оружсје (1350); све оружје своје у комате (1368); од оружја ништа не узимај (1802); око главах и оружја (1934); Све природа снабд'јева оружјем (2301); мило ми је за моје оружје (2382); обиљежја од турскога уха (2723)9.

Додир сонанта $j$ с некада палаталним $ч$ потврђен је у једном стиху: Ћуд лисичја не треба курјаку (856); док се у примјеру: лови свјетлост лисичијех очих (773) налази двосложни рефлекс -ије. Дакле, о стабилности $j$ иза „меког 4 ” придјевима и именицама (овчјu, подручје, наручје...) на основу стихова Горског вијенца не може се ништа поуздано рећи, међутим, упроштени дијалекатски лик $($ чj $>4)$, какав се биљежи у говорима његова завичаја, не потврђују ни друга његова дјела: кад откиде лаву мачју главу - из Шћепана Малог; да ми вучју трагу ископамо - из Огледала српског, примјери који се налазе у Речнику Његошева језика [Стевановић 1990: 218]. Чак ни за примјер овчи није нађена потврда, тако да је неочекиван примјер који је употријебљен у наслову једне ране Његошеве пјесме Вук пријатељь овчи [Стевановић 1990: 218]. За ликове без ј у именицама оруже, оструже, наруче Стевановић сматра да се тако данас не могу чути ни у говорима најужег пјесниковог завичаја.

Иако у Његошевом језику, у вези са континуантима старих секвенци жьju, жьја..; чьјu, чьја..., постоји одређена нестабилност, која се огледа у спорадичној употреби дијалекатског лика, може се рећи да су у правом духу Његошева језика форме са једносложним рефлексом (и код придјева и код других ријечи са сугласничком групом ж, $4+j)$; баш као и код Вука - јер фонетизам ju је у Писменици једина могућност: Божїи (30, 32); човечїи (30); као н. п. по нахиїи (окружїу) (105).

5.2. Група вљ. Завичајни говори двојице стваралаца, чије се језичке особености упоређују, показују више нестабилности од језика њихових дјела. У

(302). Рефлекс ји употријебљен је свега три пута: Божја побједа (294); закон правде Божје (296); да слуша Божју Летурђију (296).

9 За разлику од Његоша у језику његовог савременика Стефана Митрова Љубише, у овим и сличним лексемама, са рефлексом секвенци жьји, жьја..; чьји, чьја..., имамо неуједначени фонетизам: приморје приморије, оружје/оружије оруже, божји/божији/божија/божа, вражји/ вражи; и именице: обиљеже, наруче, обличе итд. [Јовановић 2011: 149-150]. 
говорима катунске нахије и другим сродним, али и многим несродним, као дублети су у употреби форме са упроштеном и неупроштеном групом, при чему су ликови са извршеним процесом вљ > $b$ често обичнија варијанта (посебно у говорима црногорског приморја). На нестабилност форми указује

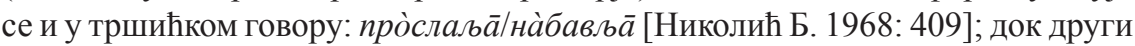
истраживач овог говора биљежи само неупроштену: постављена [Младеновић 1963-1964: 319]. И у Писменици се, међу примјерима са стабилном употребом секвенце вљ: у давно прошавшем Iвом поставльенога (52); саставльено (52); саставльасе по обштему правилу (94); по примїерима поставльеним (97); налази и један дијалекатски: да ову моїу Писменицу попра[в]льам (X). У Горском вијенцу је увијек књижевни лик: приправља сам што мрцу требује (1372); да се стављаш што си урадио (391); Приправља се, док одједном пукне (1891); но понавља оно што ђе чује (2572).

5.3. Сугласничка група $\partial н$. Тешкоћа у изговору сугласничке групе $\partial н$ (и $\partial ю$ ) у народним говорима Његошевог краја често се отклања испадањем денталне оклузиве. На примјер, у сродним, нешто јужније од Његуша, црно-

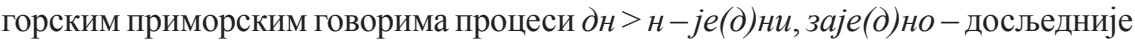
су спроведени од свих других сугласничких група, што се не може рећи за тршићки говор, гдје је група дн стабилна: једна, једној, једном [Николић Б. 1968: 410]. Правилном дистрибуцијом ове сугласничке групе (и групе дю) Вуков и Његошев језик иду истим путем, у складу са нормом књижевног језика: у Писменици - дн: їедни веле (38); неизговараїу се свуд їеднаким гласом (11); риечи коїе су по писаньу једнаке (13); іедно на и (30); два согласна писмене заїедно (30); може подниети и їедно и друго (32); и у дат. їедни (32); мїеренье качества їеднога лица (34); іедна, іедно (37); іедни веле (38); и учесћивателном природно (51); само совершителним глаголима природно (51); Ни код їеднога глагола (56); не говори свуд једнако (105); іедни зову дїевојку цуром (106). Дн је установљено и у прилогу нужно: нуждно їе знати (71); зато се види нуждно (97). Група дњ: мужескога и средньега рода (32); у мужескоме, и у средньем роду (34); кад се измїени последнье и (36); кад се промїени на е, онда средньи (36); ни у средньему двога (38); употребльаваїусе само у средньему роду (39); Средньи (48); Средньи глагол їест онаї (48). Горски вијенац: Грдни дане да те бог убије (84); на Косово у једну гробницу (136); девет пута једнако се чује (142); све је облак притиска једнако (165); а нас једне само сунце грије (168); Једна сину од Кома к Ловћену (173); Помоз, боже, јаднијем Србима (179); великаши, грдне кукавице (213); док одједном они загустише (363); усред подне тамо и овамо (1420); јадну нашу браћу соколове (1450); а зинули ка курјаци гладни (1556). Дь: па бадњаке српске налагајте (859); Каква јаја, посте и бадњаке (872); И још ћу ви једну спрдюу причат (1574); Бјеше човјек те од средње руке (1626); прекршћени на огњу бадюации (2461); вуци су ти љуто погладюели (1795). 


\section{4. Дентали $\partial$ и $m$ у претконсонантској позицији:}

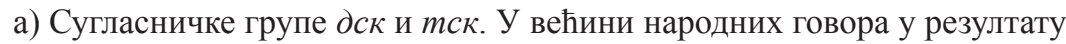
стапања дентала $\partial$ и $m$ са $c$ у сугласничким групама $\partial с к$ и $т с к$ констатује се фонетски феномен изговора африкате $u-$ у тршићком говору африката $u$ је у

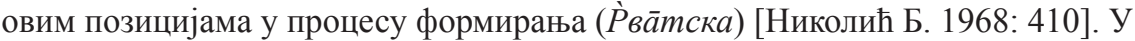
стиховима Горског вијенца нема мјеста дијалекатском лику. Дск: Куго људска, да те бог убије! (49); но си отров адске твоје душе (52); презирући људско ништавило (247); те му трагу оста за господство (373); Што се хвалиш градом и господством (385); Но отршај оволико људства! (510); бањо слатка људскога живота (913); па је носе проз градске улице (1419); људском си се крвљу опјанило (1738); Време земно и судбина људска (2290). Тск: ја за главе братско мито дати (731); Зло и добро братски дијелимо (970); Ми живимо као досад братски (1022); не могу се братски погледати (1027); а он ме је братски дочекао (1443); Не дангуби, сватски првијенче (1880); Коме браћу ти остави/братска хвало (1920); главе братске познат нећеш (1954); Ка је носиш бог-ти-братска, Станко? (823).

б) Испред суфикаса -ство. Губљење дентала $\partial$ и $m$ испред суфикса -ство, у народним говорима широких размјера, и у говорима завичаја Вукових предака је радикално спроведено: богаство, руковоство, сроство, срество, браство [Вуковић 1938-1939: 32; Станић 1974: 138]. Занемарујући стање у његушком говору, и много ширем ареалу црногорских говора, Његош у Горском вијенцу употребљава искључиво ликове у складу са књижевном нормом - -тство: Бијесна се братства истурчила (531); од богатства бјеху полуђели (1410); и -дство: Мало људство, што си засл'јепило? (888).

в) Сугласничка група $\partial c$. Изузетак у писању од правила вршења једначења сугласника по звучности, који карактерише и данашњи књижевни језик, остварен је и у Писменици и у Горском вијенцу (па гласове хвата одсвакуда - 2570) у сугласничкој групи $\partial c$ - примјери из Писменице: од предреченог правила одступа (49); коїи од овога правила мало одступаїу (94); од поставльени примїера одступаїу (100).

5.5. Сугласничка група кв. Доста је грађе за анализу ове сугласничке групе, и у Горском вијенцу и Писменици, с обзиром на њену честу реализацију у ликовима квалификативних замјеница - какав/какв-, такв-, овакв-, онакв, некакв-, никакв-. У говорима Вуковог и Његошевог краја секвенца кв- се

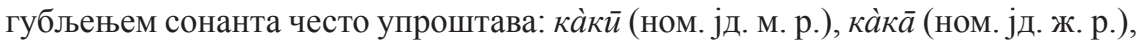
ва̀кй (ном. јд. м. р.) [Николић Б. 1968: 418]; как(в)u, как(в)а, как(в)ог, нак(в)u, онак(в)а девојка [Младеновић 1963-1964: 325], посебно у говорима Вукових предака у којима је процес кв> к готово досљедно спроведен [Станић 1974: 211; Вушовић 1927: 55]. Међутим, у Писменици и Горском вијенцу дијалекатски лик је потврђен само са по једним примјером - код Вука у фусноти 
(стр. 24): слабо се у оваким риечма чути може; код Његоша у невезаном слогу, испред стиха 1855, у којем Мустај-кадија: Моли момчад да не поју онаке пјесме покрај сакупа црногорскога. У Горском вијенцу је, осим у горњем примјеру, секвенца кв у квалификативним замјеницама стабилне употребе: Каква браћа ако бога знате (308); какве силе пут ње зијевају (852); да им даде некаква несрећа (1203); ђе упрте какву женетину (1416); Бјеху ли им какве куће, Драшко? (1423); што им такве муке ударате?(1491); Какве гусле и какву несрећу (1616); такво воће није за кавуре (1841); Кад си такву срну уловио (1843); Младе главе онакве не виђех (1971); но погодбу некакву учине (1770); ни овакве јошт није жалости (2024); Све је ово некаква наука (125); Но донеси некакве послачке (1668). Премда се јављају и у Писменици: с другом каквом риечи поміешати (14); їербо се они ни укаквом случаїу не примїеньуїу (16), а много их учесталије биљеже дијалектолози који су испитивали тршићки говор [Николић Б. 1968: 418; Младеновић 1963-1964: 325] Вук се у Писменици претежније опредјељује за ликове: такова, онакова, каково..., који се углавном везују за западније крајеве српскога језика, а на истоку се готово и не јављају (зато их нема ни у Горском вијенцу) [Стевановић 1963-1964: 83]: и неправилно сравнителни праве, такова їесу (35); Преобразност имена броїтелнога їест таково своїство (37); Такови, овакови, онакови, скланьаїусе, у сва три рода, као прилагателна имена первога скланьаньа (45); показуїе деланье какове ствари (48); такови сви глаголи окончаваїусе (49); такови глаголи їесу сльедуїућа три (49); сказуїе о ствари какової (50); а такови начина има пет (50). Штавише, пишући о „мїестоимениїу” (о „указателним”) Вук наводи само такови, овакови, онакови (44). Очигледно да су наведени ликови у говорима Вукова краја временом уступили мјесто варијантама такви/таки, какви/каки... - Младеновић за рукопис лозничких ђака (приповијетке које су 1861. године записали ђаци основне школе у Лозници, а овај их лингвиста анализира) наводи само један једини овакав примјер: није никад онакови аљина обукао [Младеновић 1963-1964: 325].

5.5.1. У говорима Његошевог ужег завичаја ове замјенице су у номинативу (акузативу) јд. м. р. обично у облику одређеног вида (-кви). Језик Горског вијенца нуди оба облика: Љубови ти, набави ми такви (1035); јер кад год сам такви сан гледао (1371); да би био овакви с очима (2368) // Какав наук, такво и читање (2069); но некакав покољ те велики (2575); кад помислим и ја какав бјеше (2043); какав народ бјеше на те стране (1401); Какав фишек на поклон везиру (1179). И примјери генитива једнине ових замјеница показују да именска деклинација у Његошевом језику, за разлику од стања у црногорским говорима, није у примјетној рецесији: И у њега некаква шишана (402); У њих нема никаква вјенчања (1769); Кад вјенчања никаква немају (1767); Самовољно, без никаква зора (1785). Додуше, нешто је обичнија придјевскозамјеничка деклинација: Онаквога сивога сокола (1980); У свијет га јошт није 
таквога (177); Ту измиље некаквога пука (1544); разговора без таквога нема (1754); Онаквога младета дизало (1973); У свијет га оваквога нема (2092). Напоредност употребе облика именичке и придјевско-замјеничке деклинације показује и Писменица: страданье каковог лица или ствари (46); показуїе страданье каковога лица (48) // А у нас никакова имена неїмаїу (29); показуїе качество какова лица или ствари (29). Такође се из Његошевих примјера види да је у Горском вијенцу, за разлику од Писменице, вокал - $a$ без изузетка саставни дио наставка генитива једнине, што је можда одговарало метричким потребама пјесниковог стиха.

5.6. Сугласничке групе $n c, n u, n u, n m$. Корпус за праћење судбине сугласничких група са плозивим $n$ на првом мјесту је и у народним говорима Вукова и Његошева краја доста оскудан, а валидна грађа се у њиховим дјелима још више смањује, тиме и могућност за давање прецизнијих оцјена. За неке групе и нема потврда (посебно у Писменици), па одређене судове о њима доносимо и на основу прилика у народним говорима - тршићком и његушком.

Група $n c$. У описима тршићког говора сугласничка група $n c$ је, испадањем плозива, редовно упроштена у глаголу псовати: сӱіе ону ђёцу, сйj $\bar{y}$, сӧва̄ли; док је у псето, псе, липсала неизмијењена [Николић Б. 1968: 408; Младеновић 1963-1964: 319]. Псовати > соват спроведено је и у говорима Вукових предака [Вуковић 1938-1939: 27] и у говору источне Херцеговине [Пецо 1963-1964: 102]. У црногорским говорима нестабилн група $n c$ у Горском вијенцу не дијели исту судбину: часне посте за пса испостио (2424), међутим, у неким Његошевим пјесмама (и у другим лексемама), према подацима Данила Вушовића, из треће деценије прошлог вијека, билабијални сугласник $n$, испред $c$,мења начин образовања (постаје лабиодентал) прелазећи у в: $a в c a$, авсу, уливсио се, всима (псима), все (псе)" [Вушовић 1927: 22]. Група пи. У лексеми пшеница судбина сугласничке групе пи на почетку ријечи у складу је са стањем у народним говорима ширег ареала, гдје се испадањем иницијалног $n$ ова секвенца упроштава: шѐница [Николић Б. 1968: 408]; Горски вијенац: пресули их бијелом шеницом (2441); у невезаном слогу, послије стиха 2647: на њој двадесет оках шенице варене; - али је у групи пшт, у медијалној позицији, према једном стиху у којем смо је нашли, стабилна: Кад близу њих сједим у скупштину (1245). У тршићком говору општина је у лику ӧвштина [Николић Б. 1968: 408]. Додири сугласника $n$ са предњонепчаним $и$ у средини ријечи нијесу у свим Његошевим дјелима стабилни. За разлику од Горског вијенца у неким његовим пјесмама, чак и Свободијади, налазе се примјери са лабиоденталним в умјесто $n$ : љевши, љевще [Вушовић 1927: 22]. У једном стиху из Горског вијенца $n$ прелази у в и испред задњонепчаног $\kappa$ : за мном црна клувка размотале (1197); а појава се потврђује и у неким Његошевим пјесмама овколили [Вушовић 1927: 22]. У тршићком говору и ова се група упроштава испадањем иницијалног $n$ : клӥко [Николић Б. 1968: 408]. Група $n$. 
Слично претходној сугласничкој групи путеве упроштавања $n \varphi>\varphi$ потврђује лексема пчела: чѐла [Николић Б. 1968: 408]; Горски вијенац: оли челе хватат у капицу (797). Група $n m$. У Горском вијенцу је, у односу на горњу секвенцу, више примјера који потврђују упроштавање секвенце испадањем $n$ у ријечи nтица: дан и народ како ћуку тиц̧а (21); Али тице те су најслабије (772); соко тражи тицу јаребицу (1877); као једна прекоморска тица (2573). Редовност упроштавања у овој лексеми потврђује и тршићки говор: тӥца [Николић Б. 1968: 408].

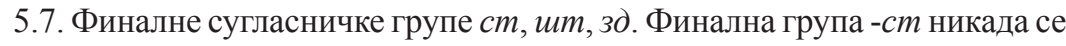
у Горском вијениу не упроштава испадањем $m$, за разлику од народних говора гдје је ова појава досљедно спроведена: могу л'оне свјетлост крити (31); Ни најест га камоли прејести (28); мунар дуби на крст раздробљени (59); Свака наша шест путах одјекне (140); за правило лудост изабраше (204); сакупили двадест тридест другах (330); направисмо петнаест носилах (418); пусти гласи милост утроструче (776); за двострукост ни мислит не треба (853); седамнаест али осамнаест (1997); Кад се шћаше ођест куд да иде (2035); дужност рађа неко попечење! (2299); чест, народност ђе је васкреснула (2353); сласт и силу изгуби причање (2374). И код Вука је у Писменици сугласничка група -cm на крају ријечи увијек реализована: истинита ревност (VIII); име їест трогубо (16); маст, кост, пропаст, cmpacm, милост, радост (17); лист (23); сласт (25); їест падеж простога народа (31); Преобразност имена броїтелнога (37); шест (37); на подобност имена прилагателнога (50); има нека различност (51); Предлог їест нескланьаеми дїел говореньа (103). Наравно, Вук је знао за упроштавање финалне сугласничке групе -cm у већини српских народних говора - па и у његовом тршићком: У Вукову чланку „Критика о језику” читамо да „у оваковијем ријечима (тј. у дванаест, тринаест)... наш народ по многијем мјестима у говору $m$ изоставља" а тако су писали и дубровачки писци код којих налазимо поред милос-милости и плаш-плашта (Граматички списи III, 194) [Пецо 1963-1964: 214-215]. Исто стање и у тршићком говору (у бројевима) потврђује Берислав Николић (стр. 273 ) - у одјељку о морфологији, говорећи о облицима бројева од 11 до 19, све форме које наводи долазе без $m$. Иначе се, осим у бројевима, у тршићком говору, према извјештајима дијалектолога који су се њиме бавили, добро чува: сулудост, чист, јест [Младеновић 1963-1964: 320 - код њега и у бројевима: шест, петнаест]; прст, пост, кост, маст [Николић Б. 1968: 408]. Код Вука чак и нема разлике између мушког рода и других родова: жалост/жалостна, радостна (104); па и у примјерима: показуї їедну годину извїестну (16); и то са извїестним предлогом (29); у извїестном времену сказуїе (50). Херцеговачки говори у овој позицији имају упрошћену сугласничку групу сm (и $u m$ ), како биљеже дијалектолози: час, глупос, корис, лис, милос, младос, опаснос, пропас, жалос; једанес, петнес; приш [Пецо 1964: 106; Вушовић 1927: 31; Вуковић 1938-1939: 32]. 
5.7.1. Констатације изречене за групу -ст потпуно су примјенљиве и за финалне сугласничке групе -шт и -зд (које су много мање фреквентности). Група -шт се ни код Вука: пришт [Пецо 1963-1964: 215], ни у тршићком говору: вешт [Николић Б. 1968: 408], ни у Горском вијенцу не упроштава: ти си јошт млад и невешт владико! (2495). Потврде за неизмијењену групу -зд - Горски вијенац: свак ће сада грозд у руку имат (1593); Докле свако за по грозд ухвати (1597); тршићки говор: гроิзд [Николић Б. 1968: 408].

\section{6. АСИМИЛАЦИЈА СУГЛАСНИКА}

6.1. Асимилација сугласника по звучности. За разлику од језика Горског вијенца гдје је једначење сугласника по звучности досљедно спроведено (то су бапске приче и мудрости - 2181; часне посте за пса испостио - 2424), у Писменици је слијед звучни + безвучни сугласник (рјеђе и обрнуто) скоро непоремећен - и то је препознатљива карактеристика Вукове граматике: безсмертну славу задобио (IX); безпристрастно не просуди (X); безпристрастно судити оће (4); сватба (25); Мужеска имена собствена на о (29); обшти (36); їедан обшти род (38); верло се риедко може чути (38); подписати (47); у спрезаньу подпомажу (49); нешто о ствари под предходом нечега (50); има време садашнье обштеобично (51); їа незнам како би другчиіе било (61); не знам како би другчиіе могло бити (63); саставльасе по обштему правилу (94); Славонци опет разтежу више (106). Готово да бисмо то могли сматрати нормалним редом, с обзиром на поједине примјере разједначавања сугласника по звучности у Писменици: него тежко ће се наћи и коїа кньига (87); сладко (103); риедко (106). Ипак, и Вук је у овој граматици спорадично уједначавао артикулацију по звучности - углавном у неким префиксалним образовањима: Време будуште од глагола карати: ако їа ускарам, ако ти ускарам, .... (66); ако усчувам (73); Време будуште од глагола творити: ако їа устворим, ако ти уствориш... (90); Време будуште од глагола карати: ако се їа ускарам, ако се ти ускараш, .... (100). И не само у засебним ријечима, и Вук и Његош знали су за једначење сугласника по звучности на граници двије ријечи - Вук: з богом, бес посла, прет кућом (Граматички списи II, 86), али сам тако никада није писао [Пецо 1963-1964: 215]; ни Његош у Горском вијенцу (јер је мука с богом ратовати! - 2392), међутим у неким другим његовим дјелима може се наћи: з друге, з Бајом, ис итапа, бес преваре, от камена [Вушовић 2013: 187].

6.2. Асимилација сугласника по мјесту и начину образовања. У позицији испред африкате $\hbar$ сугласник $c$ је у Писменици редовно неизмијењен: cласћy (25); Сва нарасћуїу у їедин. броїу (27); учесћивателни глагол (47); чесће бивао (47); нарасћуjy (107); она сва нарасћуїу у їедин. броїу на та (27); Пригледом знаменованьа могу бити глаголи учесћивателни (47); да би дїело глаголово 
чесће бивало (47); и учесћивателном природно (51); видисе као да їе учесћивателни (56). У једном примјеру $c$ није прешло у $u$ ни пред тврдом африкатом ч: ако усчувам (73), у којем је послије асимилације сугласника по звучности (узчувам $>$ усчувам) даљи процес асимилације сугласника по мјесту и начину образовања изостао. Другачије од Писменице, у Горском вијенцу сугласник $c$ испред африкате $\hbar$ (и сонанта $љ$ ) редовно прелази у $u$ : те си својом злошћу отровала (51); а ја зебем од много мишљењ $а$ (519); Јунаку се чешће путах хоће (583); крв уждену пламеном гордошћу (992); мишљљаху ли у свијет за кога? (1502); оцрњену страшћу и издајом (2273); чешће не знам што си хтио рећи (2376); са простотом и са веселошћу (2548); све радошћу дивном наравњено (2467); мишљах: скаче вода у Понору (2554); али није оно што ја мишљьах (2556); да нам пазар не смрди некршћу (2706). Међутим, у другим Његошевим дјелима могу се јавити неизмијењене секвенце $c \hbar$ : чесће, paдоchy, мудросћy и сл.; сљ: мисљасте; и съ: стијесьени [Вушовић 2013: 187]. У Горском вијенцу „нисмо наишли на алвеоло-палатализацију сибиланата $c$ и з испред слогова ле и ли испред сугласника $H$, иако се као сигурно може претпоставити да их је Његош у томе положају изговарао као ш и ж (шлика, шнага, кожле, жнам)" [Стевановић 1990: 204, 244].

\section{7. РАЗЈЕДНАЧАВАЮЕ СУГЛАСНИКА}

7.1. Група мн. У Вуковом тршићком говору група $м н$ - недосљедно је дисимилована у м $^{10}$. Поредећи Вуков језик са говорима јекавске Херцеговине, Асим Пецо констатује да овај реформатор све до 1839. године пише мл мјесто мн у ријечима са основом много, какво је стање у свим народним говорима - и архаичнијим и херцеговачким. И даје примјере из Вукових граматичких списа и преписки из тог периода, такође и из Рјечника 1818. године: млого, млогозналиа, мложење, мложина, мложити, мложити се, млоштво, млогих [Пецо 1963-1964: 214]. Међутим, у свом првом раду, у Писменици, ова група је редовно неизмијењена: о овоме много сумньао (X); Погрешки печатаньа овде има премного; има много писмена (4); много риечи (7); на много мїеста (11); под коїим се много ствари разумїеваїу (16); к овима принадлеже јошт многа имена (22); многи у овоме погріешаваїу (29); имаїу многи глаголи (94); много (103); После тога на много година (3); Он познаїе много трава (14); под коїим се многе ствари разумїеваїу (16). Дакле, изворном књижевном лику Вук ће се

\footnotetext{
${ }^{10}$ Напоредо са многе, много, многи јавља се и млого [Младеновић 1963-1964: 319], а исто стање биљежи и други дијалектолог (млӧго = много; али само: седа̀мне̄с) [Николић Б. 1968: 409]. Колебљивост мн/мл у говорима Вукових предака старији дијалектолози су биљежили и у бројевима: седа̀мле̄c, оса̀мле̄c / седа̀мне̄c, оса̀мне̄с. Међутим, у ријечи много (и сродним) ликвида л је обавезно у резултату додира носних гласова $м$ и н: млӧго, мло̀жити, умложа́вати, мло̀жење [Вуковић 1938-1939: 40; Станић 1974: 124].
} 
вратити тек двије и по деценије касније - у међувремену користиће дијалекатски дисимиловани. У стиховима Горског вијенца, за разлику од пјесниковог завичајног говора, јавља се увијек књижевни лик: а ја зебем од много мишљења (519); много ли си муке пренијело (712); многе ли те чекају побједе! (713); Трагови су многи до пећине 1158); Народа се бјеше много дигло (1309); ма бих река да их није много (1713); многе ли си војске запамтило (1735); многе ли си мајке ојадило! (1736); на много се мјестах догађало (2025); Ја сам многа зажега канђела (2247); Ја сам много обиша свијета (2259).

7.1.2. Дестабилизација правилног изговора носних гласова мн може ићи и у другом правцу, до измјене првога гласа из консонантске групе који прелази у в. Тако је, на примјер у Горском вијенцу редован прелазак $м н>$ вн у лексемама тамнииа и гумно: но тавнице за невољне сужње (389); затворила вилу у тавнииу (484); дријемају у морској тавници (789); Најгоре им пак бјеху тавнице (1474); познао сам на оне тавнице (1497); // гувно му је код куће лијепо (1709); Купимо се на мједено гувно (2141); у невезаном слогу, послије стиха 2647: Момци поставише кољиво насред великога гувна. То је особина говора који су ушли у основицу српског књижевног језика, као што је говор Пиве и Дробњака [Вуковић 1938-1939: 41], у тршићком говору биљежи се и гу́мно и гу́вно [Николић Б. 1968: 409]. У писму Л. Мушицком од 26. I 1822. Вук каже да тамница (исто као гумно и много) може „остати за невољу, зашто може бити да би се ђе нашло и прости људи, који тако изговарају” (Преп. I, 284) [Пецо 1963-1964: 214 - фус. 145].

7.2. Група $\hbar$. Сугласничка група $\hbar н$ у Горском вијенцу може бити, као и у књижевном језику, очувана: А ђе ви је та злосрећна баба (2122); а кроз Турке несрећну невјесту (496); Откуд дође та несрећна миса (966); Притиска ме све несрећна мора (1230); Ада ова несрећна невјеста (2019); или као у народном говору пјесниковом дисимилована: а камоли чојка несретьега (1480); но с планине у прољетье јутро (909); Ћескота их несретња дављаше (1426). Напоредност књижевног и дисимилованог лика показује и Вуков тршићки говор, при чему је дисимиловани веће очекиваности: срётна = срёћна; помо̀т'юиик,

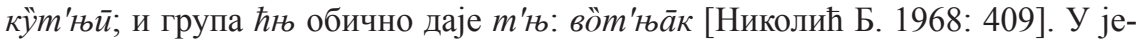
дином примјеру из Писменице (12) сугласничка група ћн је реализована без промјене: їа сам несрећна друга.

8. Иако је Вуков језик у Писменици још у извјесној мјери славеносербски, а Његош у Горском вијенцу између књижевног и дијалекатског лика често бира дијалекатски (но он никада није усколокалног завичајног цетињско-његушког типа, већ увијек много ширег простирања), два извора, чије смо одређене фонетско-фонолошке особине поредили, показују виши степен сагласности него што би се на први поглед очекивало (међутим, ни разлике нијесу занемарљиве). Очигледно је да се сличности сретају на тачки заједничког стремљења оба дјела - на стварању новог модела књижевног језика, заснованог на народним гово- 
рима. У том погледу, значај и вриједност Писменице се не смије потцијенити - мада доста богати језички материјал није увијек на прави начин изнесен, због чега се ова граматика може чинити непотпуном и несавршеном. Белић Писменицу (и Рјечник из 1818. године) сматра дјелима „прве вредности и првог значаја у науци о нашем језику се - што је свима језичким особинама дат прави облик и што су оне увек црпене из непомућена извора. У њој нема више колебања и тражења: све је поуздано обележено према народном говору" [Белић, 1998: 81]. Снага и моћ језика Горског вијенца, чију је структуру често опредјељивао и ритамски моменат, доказивали су исправност Вуковог мукотрпног пута на спровођењу реформи и коначној побједи.

\section{ЛИТЕРАТУРА}

Амфилохије (Радовић) 2013: Амфилохије Радовић, Житије светог митрополита Петра Другог - иетиюског пустињака и ловћенског тајновидиа. Никшић: Слово (часопис за српски језик, књижевност и културу), бр. 42, 289-302.

Белић 1998: Александар Белић, О великим ствараоиима. Београд: Завод за уџбенике и наставна средства.

Бећковић 2013: Матија Бећковић, Свети Петар II Петровић Његош - пустиљак иетињски. Никшић: Слово (часопис за српски језик, књижевност и културу), бр. 42, 303-310.

Вуковић 1938-1939: Јован Вуковић, Говор Пиве и Дробњака. Београд: ЈФ XVII, 1-114.

Вушовић 1927: Данило Вушовић, Диалект источне Хериеговине. Београд: СДЗб ІІІ, 1-71.

Вушовић 2013: Данило Вушовић, О Његомевом језику. Никшић: Слово (часопис за српски језик, књижевност и културу), бр. 42, 172-192.

Јовановић 2011: Миодраг Јовановић, Полугласници и јат у ирногорским говорима. Подгорица: ЦАНУ, Посебна издања (монографије и студије), књ. 82, Одјељење умјетности, књига 23.

Јовановић 2013: Миодраг Јовановић, Придјевско-замјеничке ријечи у Горском вијениу. Подгорица: ЦАНУ, Гласник Одјељења умјетности, књига 31, 49-69.

Јовановић 2014: Миодраг Јовановић, Финалне вокалске групе и покретни вокали у Вуковој ,Писменици” и Његошевом „Горском вијениу”. Подгорица: Октоих бр. 5, часопис Одјељења за српски језик и 
књижевност Матице српске - Друштва чланова у Црној Гори, $7-28$.

Милетић 1940: Бранко Милетић, Црмнички говор. Београд: СДЗб IX, 211-663.

Младеновић 1963-1964: Александар Младеновић, Језичке особине Вукова краја из 1861. године. Београд: ЈФ XXVI, св. 1-2, 293-336.

Младеновић 1989: Александар Младеновић, Књига о Његошу. Београд: НИРО „Књижевне новине”, Горњи Милановац: НИРО „Дечје новине".

Николић Б. 1958: Берислав Николић, Данашьи тршићки говор. Београд: ЈФ XXIII, 263-274.

Николић Б. 1963-1964: Берислав Николић, Однос данашъег тршићког говора према Вуковом језику. Београд: ЈФ XXVI, св. 1-2, 151-176.

Николић Б. 1968: Берислав Николић, Тршићки говор. Београд: СДЗб XVII, $371-472$.

Остојић 1976: Бранислав Остојић, Језик Петра I Петровића. Подгорица: ЦАНУ, Посебна издања, Књига 8, Одјељење умјетности, Књига 1.

Пецо 1963-1964: Асим Пецо, Једно поређење Вукова језика са говорима јекавске Хериеговине. Београд: ЈФ XXVI, св. 1-2, 177-218.

Станић 1974: Милија Станић, Ускочки говор. Београд: СДЗб ХХ, 1-259.

Стевановић 1935: Михаило Стевановић, Источночрногорски дијалекат. Београд: Библиотека ЈФ V, 1-129.

Стевановић 1963-1964: Михаило Стевановић, Језик у Вукову делу и савремени српскохрватски књижевни језик. Београд: ЈФ XXVI, св. $1-2,73-150$.

Стевановић 1990: Михаило Стевановић, О језику Горског вијенца, Његошев књижевни језик. Београд: САНУ, Научна књига, 202-246.

Тепавчевић 2010: Миодарка Тепавчевић, Језик Стефана Митрова Љубите. Подгорица: ЦАНУ, Посебна издања (монографије и студије), књ. 70, Одјељење умјетности, књ. 19. 


\title{
A COMPARISON OF SOME OF THE PHONETIC-PHONOLOGICAL FEATURES OF THE WORKS PISMENICA AND GORSKI VIJENAC AND THE SPEECH OF THE AREAS WHERE VUK AND NJEGOŠ ORIGINATED FROM
}

\begin{abstract}
Summary
A comparison of certain phonetic-phonological features of Vuk's Pismenica and Njegoš's Gorski vijenac have indicated a greater degree of concurrence than was expected at the beginning of the study - although the differences were not negligible either. Both of these authors introduced into their work, to a great extent, the features of their folk tongues (for Vuk that was the Hercegovački speech which would find its way into the foundations of what is the modern Serbian language today; Njegoš derived the endless power and might of his poetry from the wealth of the folk speeches). However, the ultimate goal they had in common: their linguistic expression was meant to be (and was) a guideline for the creation of an official language - following the dedicated work on both their parts. Which is why, on their joint paths, these two sources coincide in a variety of ways; and the differences can also be understood: the Pismenica is a scientific, and Gorski vijenac a work of poetry in which the choice of characters is often conditioned by the requirements of the meter.

Key words: Pismenica, Gorski vijenac, the speech of the Tršić area, the speech in the njeguš' region, consonant clusters, the consonants $j$ and $f$, alternations of consonants, official language.
\end{abstract}

